\title{
D-18 REVIEW OF THE REMAINING POTENTIAL IN THE EASTERN SIRTE BASIN, LIBYA
}

Schlumberger Oilfield Services, Schlumberger House, Buckingham Gate,

Gatwick Airport West Sussex RH6 ONZ, UK

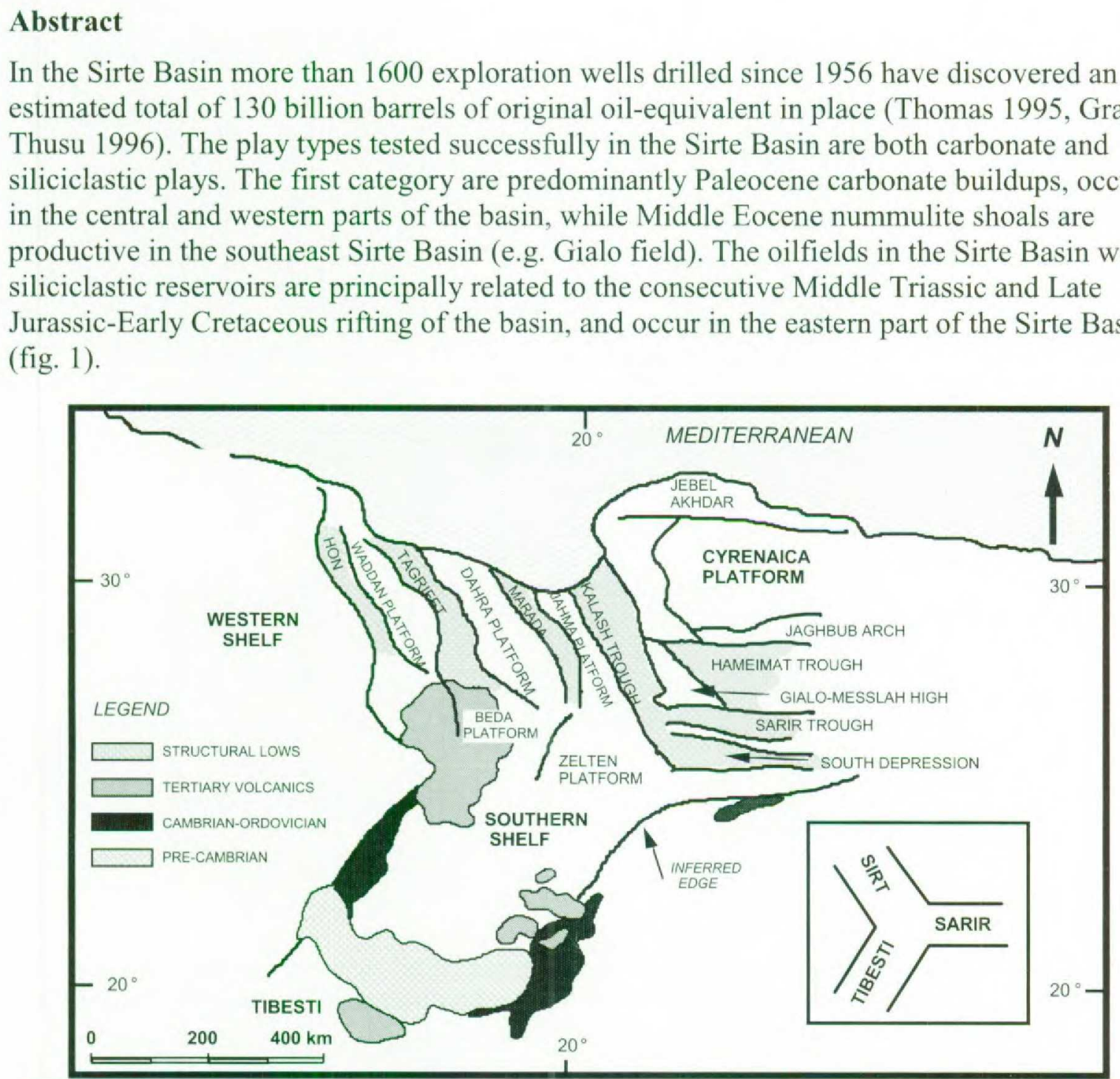

Figure 1: Structural overview of the Sirte Basin. Study area is the Sarir area, east of the $21^{0} \mathrm{E}$ parallel 
The 34 fields in the eastern Sirte Basin east of the $21^{0}$ E parallel are estimated to hold 65 billion barrels of original oil in place. The limits of the productive and prospective play fairway area are as yet poorly defined, and the total area is estimated to cover approximately $80000 \mathrm{~km}^{2}$. Approximately $90 \%$ of the OOIP is contained in the seven giant fields Sarir C-Main, Sarir LField, Messlah, Gialo, Nafoora-Augila, Abu Attifel, and Amal. The remaining 27 fields, on average, hold 200 million barrels OOIP. Estimates of the average expected recovery factors for the fields in the eastern Sirte Basin are in the range of 15-30\% (Thomas 1995, Gras \& Thusu 1998).

The reservoirs in the Eastern Sirte Basin occur in the pre-rift, syn-rift or post-rift sequences (Fig. 2). However, the most frequently proven and prospective reservoir intervals are the Middle Triassic and Late Jurassic-Early Cretaceous clastic reservoirs.

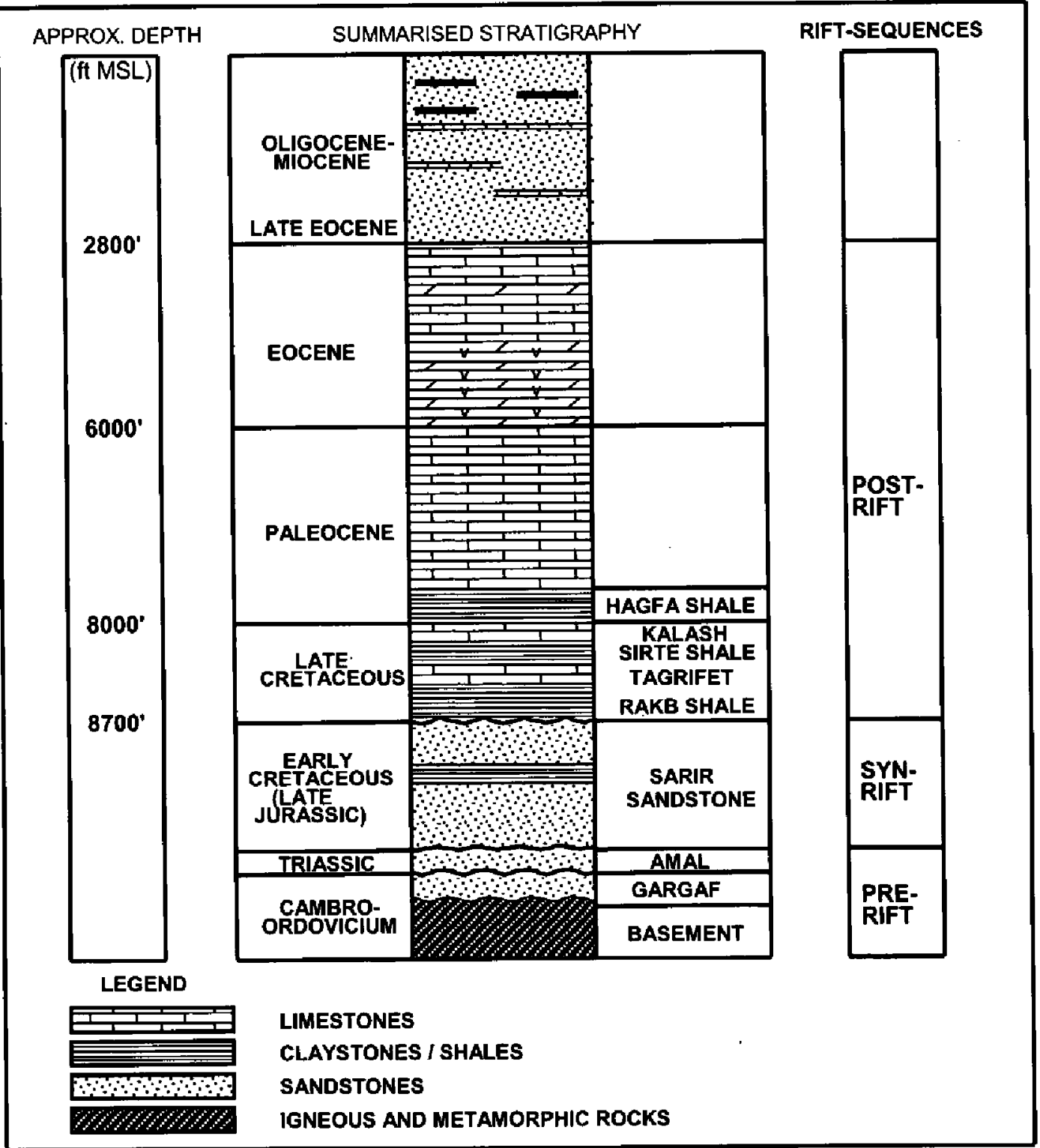

Figure 2: Schematic stratigraphy, eastern Sirte Basin 
The Triassic syn-rift sediments in the eastern Sirte basin (Maragh Trough) are deep water turbidites. The best reservoir facies is to be found in the deep grabens close to the basin margins. The turbidite sandstones are embedded in a shales, acting as both source and seal. These reservoirs are a new type of exploration target in Libya, to be found in the deep basins off the structural highs (Klauser-Baumgartner \& Kuehn, 1999). The Triassic rift related sediments have been named the Amal Formation, and have also been shown to locally contain oilprone organic matter (Thusu 1993).

The Late Jurassic-Early Cretaceous syn-rift reservoir is the prolific Sarir sandstone, hosting a number of giant oilfields. The Sarir sandstone is the principal reservoir in the eastern Sirt Basin. In this area the main phase of the rifting took place in the Late Jurassic-Early Cretaceous, during which time the Sarir sandstone was deposited as a non-marine, intra-continental clastic syn-rift sequence. The Sarir lithostratigraphic framework comprises four regionally correlatable members, linked to regional baselevel changes and comprising the main producing intervals (Ambrose 2000).

The siliciclastic play types are both structural traps, combined structural-stratigraphic traps, and stratigraphic traps. In the eastern Sirte Basin the distribution of oil fields mirrors the main structural trends. Traps on the E-W structural trend are fault dependant with both footwall and hanging wall plays. On the NW-SE trend fourway dip closures dominate. These dip closures together with stratigraphic plays make the NW-SE trend most important in terms of OIP and productivity, However, the E-W trend is more lightly explored and offers greater future potential.

Trap geometries are often influenced by E-W trending, basement-controlled fault systems, oblique to the NW-SE Sirt Basin trend. The E-W trending fault systems are frequently developed in en-echelon patterns, as a result of the NW-SE trending extension of the Sirt Basin superimposed upon the pre-existing structure. The fault systems were active during the Sarir sandstone deposition, giving rise to structural as well as combined structural-stratigraphic traps (Gras 1998). An increased understanding of trap architecture has led to re-evaluation of older fields, in addition to new discoveries and prospects.

The eastern Sirte Basin is in an immature stage of exploration, in comparison with the North Sea, a similar rift system. Both the Sirte Basin and the Central North Sea are multiphase rift systems with major extension taking place during the Late Jurassic to Early Cretaceous, and with world class oil reserves accumulated in the syn-rift siliciclastic sedimentary sequence. Comparison of exploration statistics in both basins supports the remaining potential of the Sirte Basin. This potential is expected to be reservoired in both combined structural-stratigraphic traps, complex structural traps, and deeper, as yet poorly tested deeper reservoirs such as the Triassic Amal Formation..

The major fields in the eastern Sirte Basin have been detected with gravity and magnetics and early 2D-seismic, however, 3D seismic data is utilised increasingly for exploration and development purposes. Implementation of new technology in land seismic acquisition, processing and integrated interpretation, as well as the use of the latest concepts of sequence stratigraphy and structural interpretation will lead to further discoveries in the 20-200 million OIP barrels range. El Ghoul \& Hallett (1993) stress that to date relatively shallow targets have been explored, as only $10 \%$ of the exploration wells in the Sirte Basin have drilled deeper than $10000 \mathrm{ft}$. Only rarely have deviated or horizontal wells been undertaken in the Sirte Basin. 


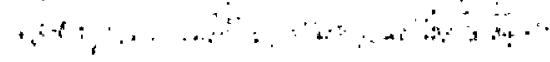

Advances in integrated reservoir management and enhanced oil recovery have the potential to dramatically increase recovery rates. The geológiçal concepts and leading edge technology utilised in the appraisal, development, production and enhanced recovery schemes in the North Sea are expected to guide the future trends in the exploration and development of the eastern Sirte Basin.

\section{Cited references:}

Ambrose, G.J., 2000. The geology and hydrocarbon habitat of the Sarir Sandstone, southeast Sirt Basin Libya. Journal of Petroleum Geology (in press).

El-Ghoul, E. \& D. Hallett, 1993. Oil and gas potential of the deep trough areas in the Sirt Basin, Libya (Abst.). Sedimentary basins of Libya, First Symposium, Geology of the Sirte Basin, Tripoli.

Gras, R., 1998. Statistical analysis of syn-rift sediments - an example from the Sarir sandstone, Messlah Field, Sirte Basin, Libya. Journal of Petroleum Geology 21, No. 3, pp. 329-342.

Gras, R and Thusu, B., 1998. Trap architecture of the Early Cretaceous Sarir sandstone in the eastern Sirte Basin, Libya. Special Publication of the Geological Society London 132, pp. 317334.

Klauser-Baumgartner, D. \& Kuehn, M., 1999; Seismic stratigraphy, sedimentology and reservoir potential of syn-rift turbidites (Maragh Trough, Sirt basin, Libya). (abst.). AAPG Bulletin, 83, No. 8, p.1323.

Thusu, B., 1993. Implication of the discovery of reworked and in-situ Late Palaeozoic and Triassic palynomorphs on the evolution of the Sirt Basin, Libya (Abst.) Sedimentary basins of . Libya, First Symposium, Geology of the Sirte Basin, Tripoli. 